\title{
INTERACTION OF CLAY MATERIALS WITH LEAD IN AQUEOUS SOLUTIONS
}

\author{
Kypritidou Z. ${ }^{1}$, Argyraki A. ${ }^{1}$, Chryssikos G. ${ }^{2}$ and Stamatakis M. ${ }^{1}$ \\ ${ }^{I}$ Faculty of Geology and Geoenvironment, University of Athens, Panepistimiopolis Zografou, \\ Athens 157 84, Greece, zach-kyp@geol.uoa.gr \\ ${ }^{2}$ Theoretical and Physical Chemistry Institute, National Hellenic Research Foundation, 48 Vass. \\ Constantinou Avenue, Athens 11635, Greece, gdchryss@eie.gr
}

\begin{abstract}
Five bulk clay samples were characterized by XRD, XRF, FTIR and SEM and tested for their effectiveness in removing lead ions from aqueous solutions. These were pal ygorskite, smectite and mixed palygorskite/smectite clays from Macedonia, Greece, as well as a montmorillonite-rich sample from Kimolos, Greece, and a palygorskiterich sample from Western Australia]. Lead removal was investigated as a function of the $\mathrm{pH}$ and ionic strength of the suspensions, the amount of sorbent and time, at con stant $\mathrm{Pb}^{2+}$ concentration $(50 \mathrm{mg} / \mathrm{L})$ and temperature $\left(22^{\circ} \mathrm{C}\right)$. The greatest potential fo $r \mathrm{~Pb}^{2+}$ removal was found for the natural palygorskite/smectite clay.
\end{abstract}

Keywords: palygorskite, smectite, montmorillonite, removal, lead.

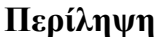

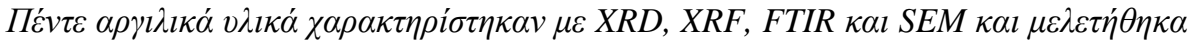

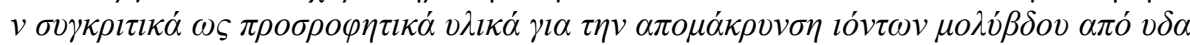

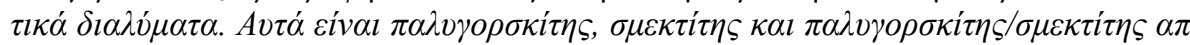

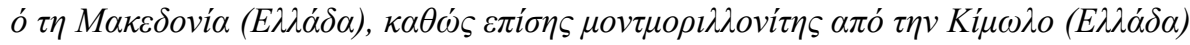

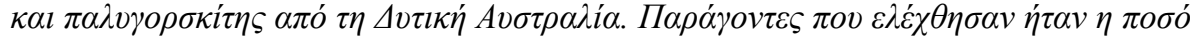

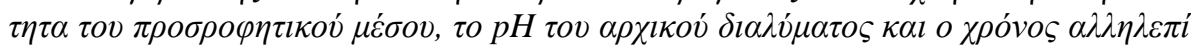

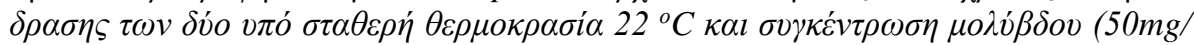

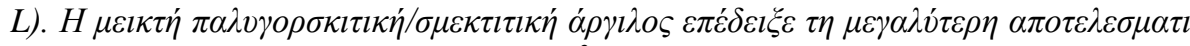

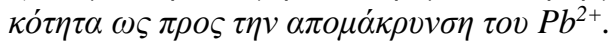

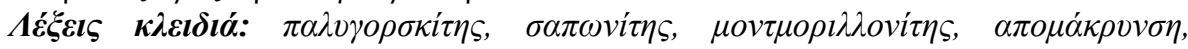
$\mu o ́ \lambda v \beta \delta o \varsigma$.

\section{Introduction}

Clay minerals are well-known for their removal ability. Many laboratory studies have been conducted to investigate the ability of clay minerals to remove heavy metals including $\mathrm{Pb}, \mathrm{Cu}$ and Cd from monometallic or polymetallic ideal solutions (e.g. Bourliva et al., 2013; Malamis et al., 2013; Potgieter et al., 2006). The ultimate goal of such studies is the fundamental understanding of the factors and mechanisms that control the interaction between metal ions and clay materials. In this way, conclusions can be drawn about the impact of ion-exchange, removal and precipitation on the mobility and distribution of contaminants in the environment. 
Within this framework, the main objective of the present work is to present preliminary data on the comparison of different clay materials regarding their effectiveness in the removal of lead from aqueous solutions.

\section{Materials and Methods}

\subsection{Materials}

The tested palygorskite (PCM), smectite (SCM) and mixed palygorskite-smectite (MCM) clay samples originate from the Ventzia Basin clay deposits, Grevena (West Macedonia, Greece), exploited by Geohellas S.A. They are considered alteration products of primary ultramafic rocks of the Vourinos complex (Kastritis et al., 2003). An additional palygorskite sample (AT_AUS) originating from the Lake Nerramyne deposit in Western Australia, exploited by Hudson Resources Ltd. was used for comparison, as it is considered of sedimentary origin. Finally, the montmorillonite clay sample (KIM) was extracted by one of the authors (MGS) from the Prassa Quarry (Bentomine Enterprises), north Kimolos Island (SW Cyclades, Greece). The Kimolos clay deposit was formed by the alteration of volcanic ash in a shallow marine environment (Christidis, 1998). All samples were milled and sieved below $250 \mu \mathrm{m}$ particle size.

\subsection{Methods}

Clay morphology was examined by scanning electron microscopy (SEM) (JSM-5600) operating at 25-30 kV. Sample mineralogy was determined by powder X-Ray Diffraction (XRD) analysis (Siemens D5005, with $\mathrm{Cu}$ radiation operating at $40 \mathrm{kV}$ and $40 \mathrm{~mA}$ ) with 2-theta range from 3 to $45^{\circ}$, step $0.02^{\circ}$ and step time $2 \mathrm{sec}$ at ambient condition. Mineralogical evaluation was conducted using the DIFRAC PLUS v2.2 software by Siemens. SEM and XRD analysis was performed in the Laboratory of Economic Geology and Geochemistry, NKUA. Mid-infrared (ATR) and near-infrared (NIR) spectra were measured using Fourier transform instruments equipped with a single reflection diamond accessory (Equinox 55 by Bruker Optics) and a powder probe optical fiber (Vector 22N by Bruker Optics), respectively, at the Theoretical and Physical Chemistry Laboratory of the National Hellenic Research Foundation. Measurements were obtained at $4 \mathrm{~cm}^{-1}$ spectral resolution and averaging a total of 100 and 200 scans for ATR and NIR respectively. The spectra are presented in the $2^{\text {nd }}$-derivative mode (for better resolution of sharp weak bands) calculated by the OPUS v4.2 software (Bruker Optics).

Chemical analysis of the samples was carried out by X-Ray Florescence (XRF) in the laboratories of Titan Cement Company SA. The following analytical procedures were carried out at the Laboratory of Economic Geology and Geochemistry, NKUA. Cation exchange capacity (CEC) was determined by the ammonium acetate extraction method (Rhoades, 1990). It is noted that the used method is developed for soils and represents the "early" CEC, at least for the smectite-rich clay materials, rather than the complete CEC due to insufficient saturation of exchangeable cation sites with ammonium cations. Batch removal experiments were carried out to study the removal of lead. An appropriate quantity of $\mathrm{Pb}\left(\mathrm{NO}_{3}\right)_{2}$ (analytical grade) was dissolved in highly purified water (MilliQ) to make a $50 \mathrm{mg} / \mathrm{L} \mathrm{Pb}^{+2}$ solution. The calculated amounts of solid, weighted after equilibration at ambient (moisture content $\sim 10 \%$ ) were dispersed in $25 \mathrm{ml}$ of the $\mathrm{Pb}^{+2}$ solutions in $50 \mathrm{ml}$ Erlenmeyer flasks, shaken in a thermostatic chamber at constant temperature $\left(22^{\circ} \mathrm{C}\right)$ for the desired amount of time and filtered through $0.45 \mu \mathrm{m}$ membrane filters. The effect of adsorbent content was studied using solid/liquid ratios of $1-20 \mathrm{~g} / \mathrm{L}$ and a shaking time of $24 \mathrm{~h}$, at natural solution $(\mathrm{pH} 4.5)$. Preliminary feasibility experiments led to kinetic measurements at $10 \mathrm{~g} / \mathrm{L}$ solids for up to $24 \mathrm{~h}$ (1440min). The influence of the $\mathrm{pH}$ of the initial solution $(\mathrm{pH}=2-6)$ was examined at $10 \mathrm{~g} / \mathrm{L}$ material with shaking time of $4 \mathrm{~h}$. The solution $\mathrm{pH}$ was adjusted prior to the addition of clay by adding drops of $0.1 \mathrm{~N} \mathrm{HNO}_{3}$ or $0.1 \mathrm{~N} \mathrm{NaOH}$ and measured by a bench-top pH-meter (Jenway 3040 Ion Analyzer) calibrated by using buffer solutions of $\mathrm{pH} 4$ and 7 . The influence of ionic strength was studied by dissolving proper amounts of $\mathrm{KNO}_{3}$ or $\mathrm{NaNO}_{3}$ (analytical grade) to obtain $0.01-0.1 \mathrm{M}$ solutions. All 
samples were analyzed in triplicate giving the average value and standard deviation for each set. Procedural blank solutions containing only $\mathrm{Pb}\left(\mathrm{NO}_{3}\right)_{2}$ as well as zero $\mathrm{Pb}$ concentration suspensions of clays were also included in the analysis for quality control purposes. Lead concentration was determined by flame atomic removal spectroscopy (F-AAS) using a Perkin Elmer 603 instrument. Filtered samples were stored at $4^{\circ} \mathrm{C}$ prior to analysis.

\section{Results}

\subsection{Material characterization}

Preliminary mineralogical analysis showed that the Grevena samples are composed mainly of palygorskite (PCM, 70\%; MCM, 20\%), smectite (SCM, 70\%; MCM, 40\%, PCM 20\%) and contain additionally, quartz, serpentine (MCM, SCM, PCM) and plagioclase admixtures (Figure 1 $\& 2)$. Australian palygorskite sample consists of palygorskite $(\sim 50 \%)$, kaolinite $(\sim 20 \%)$, and quartz $(\sim 15 \%)$ with traces of halite, whereas the Kimolos sample (KIM) consists of montmorillonite $(\sim 60 \%)$, zeolite and opal-CT (Figure 3).

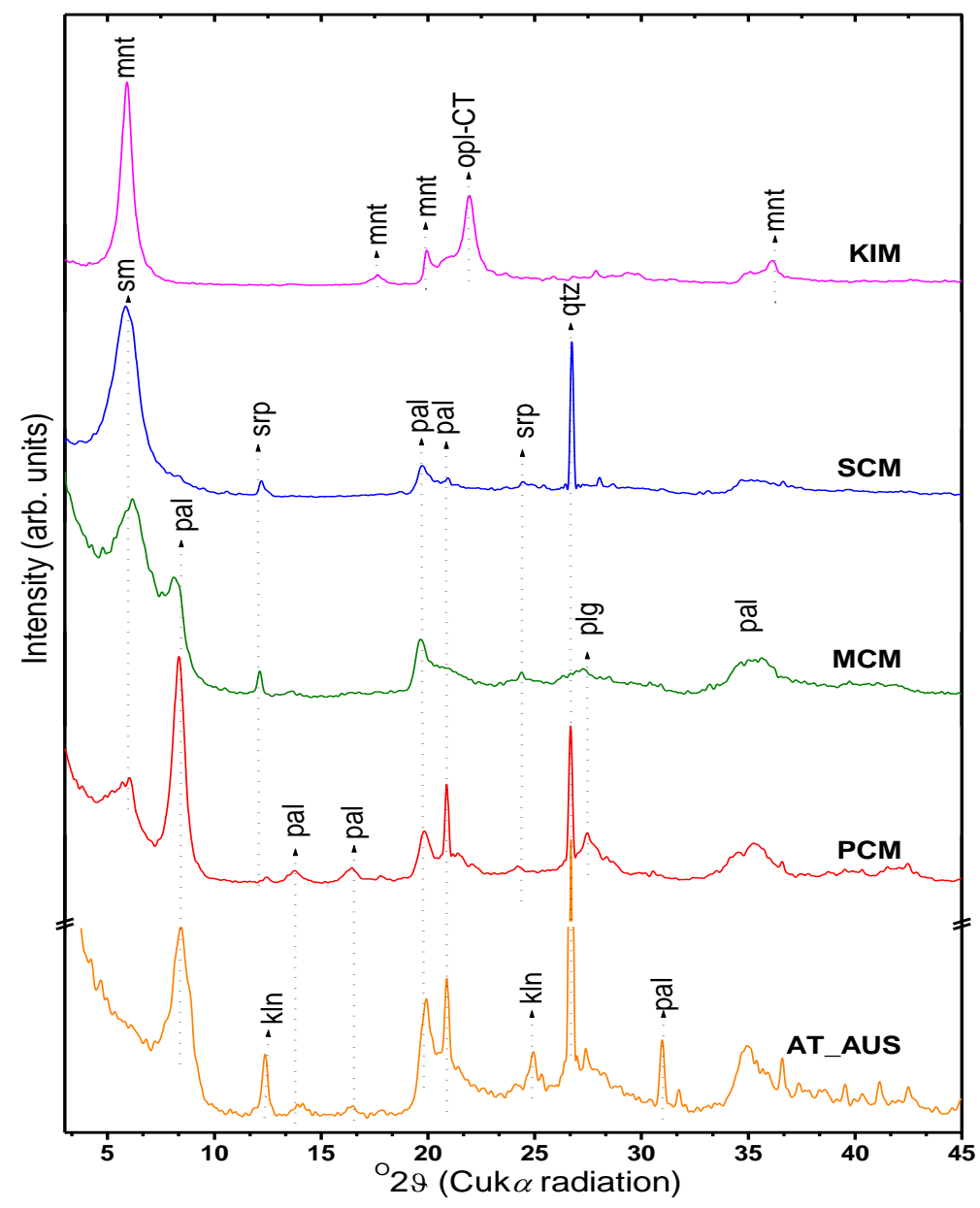

Figure 1 - XRD patterns of clay samples ( $\mathrm{sm}=$ grevena smectite, mnt=montmorillonite, pal=palygorskite, kln=kaolinite, srp=serpentine, opl=opal-CT, qtz=quartz, plg=plagioclase). 
The ATR and NIR spectra (Figure 2) exhibit the main stretching (overtone) modes of the various structural $\mathrm{OH}$ groups at $3685(7212-7185) \mathrm{cm}^{-1}$ for $\mathrm{Mg}_{3} \mathrm{OH}, 3620$ (7065) $\mathrm{cm}^{-1}$ for $\mathrm{Al}_{2} \mathrm{OH}, 3585$ (6995) $\mathrm{cm}^{-1}$ for $\mathrm{AlFeOH}$, and 3545 (6927) $\mathrm{cm}^{-1}$ for $\mathrm{Fe}_{2} \mathrm{OH}$ (Gionis et al., 2007; Madejova, 2003). The relative intensities of these bands indicate that the palygorskite in the Grevena samples has a mixed dioctahedral-trioctahedral character (Stathopoulou et al., 2011; Gionis et al., 2007) and is rich in Fe(III). On the contrary, AT_AUS is almost exclusively dioctahedral and of low Fe-content. With reference to the general formula:

$\mathrm{yMg}_{5} \mathrm{Si}_{8} \mathrm{O}_{20}(\mathrm{OH})_{2} \cdot(1-\mathrm{y})\left[\mathrm{xMg}_{2} \mathrm{Fe}_{2} \cdot(1-\mathrm{x}) \mathrm{Mg}_{2} \mathrm{Al}_{2}\right] \mathrm{Si}_{8} \mathrm{O}_{20}(\mathrm{OH})_{2}$

and the analysis in Chryssikos et al. (2009), palygorskite in PCM has (x, y) values of $(0.41,0.06)$, in comparison to $(0.78,0.48)$ for MCM, and $(0.11,0)$ for AT_AUS.

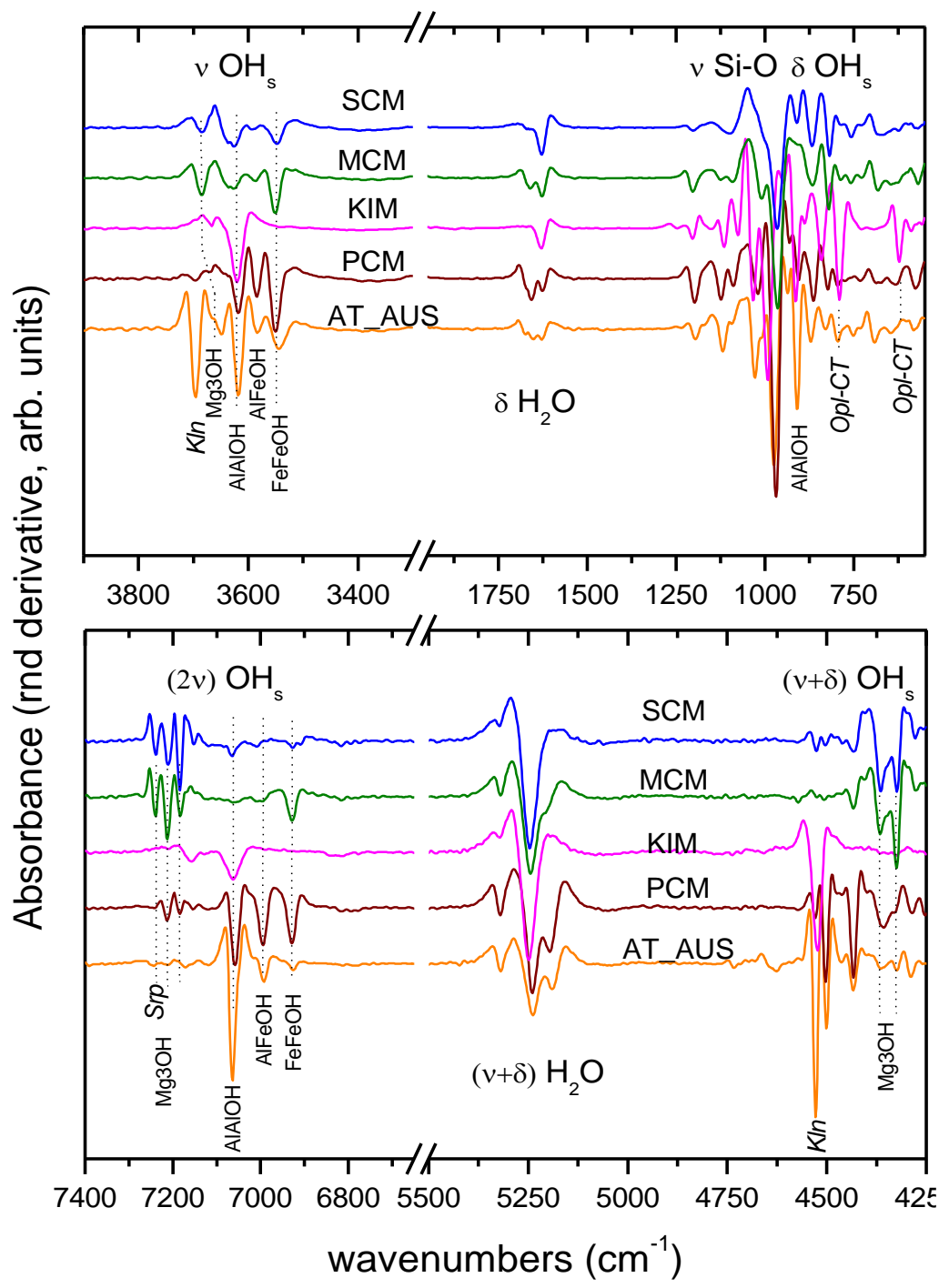

Figure 2 $-2^{\text {nd }}$ derivative ATR (upper) and NIR (lower) spectra of the clays investigated. Main assignments are included, for details see text.

The smectite in KIM is clearly dioctahedral (montmorillonite). However, the nature of the smectite in SCM and MCM can be controversial and requires further investigation. On one hand, the presence 
of $\mathrm{Mg}_{3} \mathrm{OH}$ overtones at $7183 \mathrm{~cm}^{-1}$ and $7151 \mathrm{~cm}^{-1}$ in the spectra of SCM and MCM samples suggest the presence of a trioctahedral type, similar to talc or saponite (Gionis et al., 2007). On the other hand, the presence of the relatively broad band at $\sim 3550 \mathrm{~cm}^{-1}$ in SCM (that contains no palygorskite) signals the presence of ferruginous smectite or nontronite, in agreement with Christidis et al. (2010).
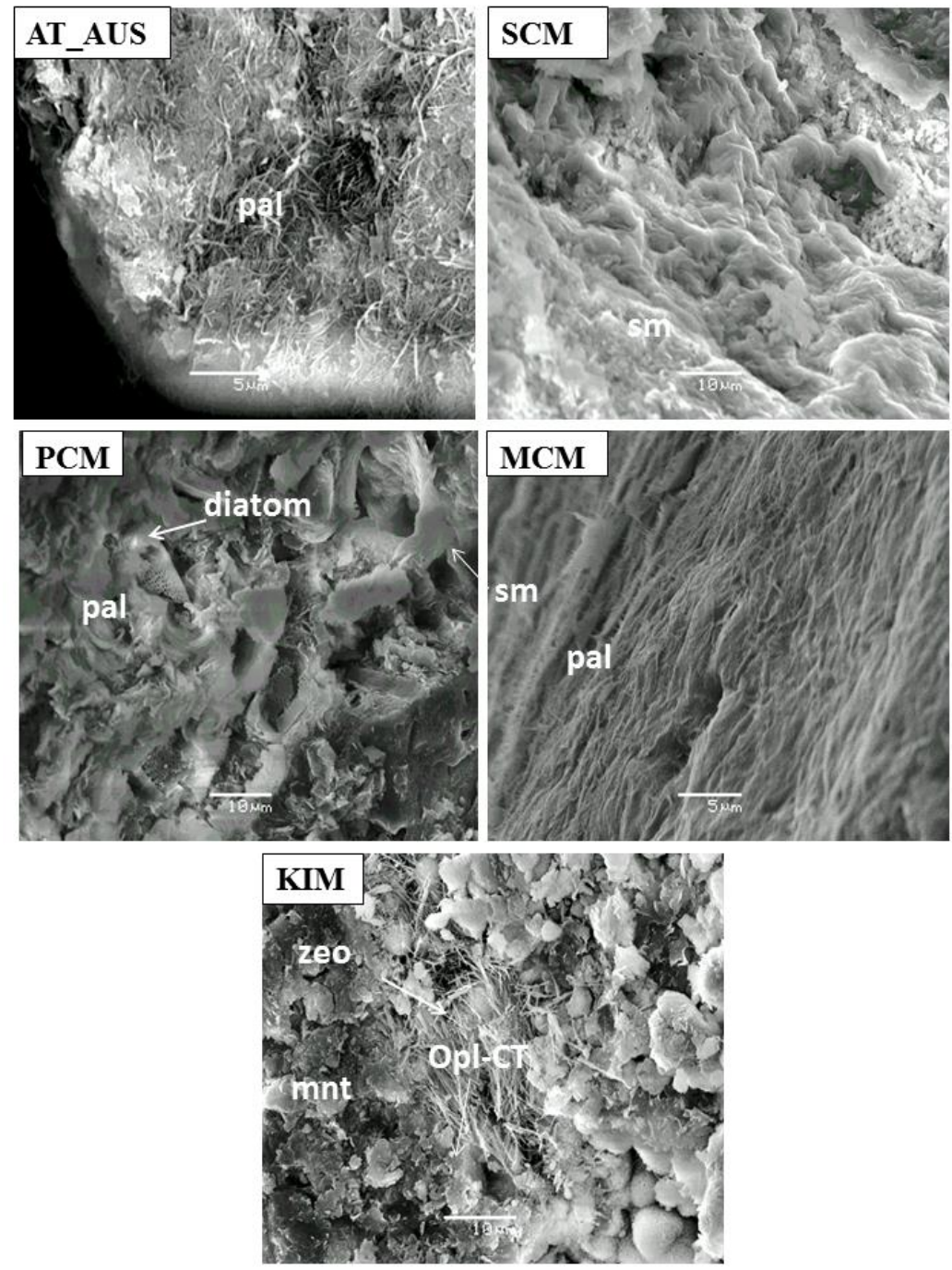

Figure 3 - SEM images of the clay samples (pal=palygorskite, sm=smectite, zeo=zeolite, mnt=montmorillonite, opl-CT=opal-CT).

SEM images show a typical fibrous texture for palygorskite (AT_AUS, PCM) and a flaky texture for smectites (SCM, KIM). In the MCM sample the palygorskite fibers are in contact with saponite flakes. In PCM samples diatom fragments and primary silicate minerals were detected. KIM samples show flakes of montmorillonite alongside with fibrous spheres of opal and acicular zeolite (mordenite) (Figure 3).

The chemical characteristics of clay samples are summarized in Table 1. 
Table 1 - Chemical composition (\%wt) and cation exchange capacity of clay samples.

\begin{tabular}{|l|r|r|r|r|r|}
\hline Compound & PCM & AT_AUS & SCM & KIM & MCM \\
\hline $\mathrm{SiO}_{2}$ & 58.09 & 56.41 & 54.98 & 78.13 & 60.24 \\
\hline $\mathrm{TiO}_{2}$ & 0.42 & 0.67 & 0.24 & 0.10 & 0.14 \\
\hline $\mathrm{Al}_{2} \mathrm{O}_{3}$ & 5.15 & 10.06 & 3.05 & 11.06 & 0 \\
\hline $\mathrm{Fe}_{2} \mathrm{O}_{3}$ & 5.91 & 2.91 & 9.30 & 0.89 & 9.90 \\
\hline $\mathrm{MnO}$ & 0.04 & 0.03 & 0.15 & 0.01 & 0.15 \\
\hline $\mathrm{MgO}$ & 12.16 & 5.71 & 18.92 & 6.14 & 27.52 \\
\hline $\mathrm{CaO}$ & 3.09 & 1.77 & 1.36 & 0.74 & 1.17 \\
\hline $\mathrm{Na}_{2} \mathrm{O}$ & 0 & 0 & 0 & 1.81 & 0 \\
\hline $\mathrm{K}_{2} \mathrm{O}$ & 0.55 & 1.58 & 0.44 & 0.70 & 0.13 \\
\hline $\mathrm{P}_{2} \mathrm{O}_{5}$ & 0.03 & 0 & 0.025 & 0.01 & 0.03 \\
\hline $\mathrm{SO}_{3}$ & 0.02 & 0.20 & 0.06 & 0.23 & 0.14 \\
\hline $\mathrm{Cl}$ & 0 & 1.02 & 0 & 0.07 & 0.14 \\
\hline $\mathrm{LOI}$ & 14.16 & 19.47 & 10.72 & 0 & 0 \\
\hline Total & 99.64 & 99.85 & 99.19 & 99.87 & 99.55 \\
\hline $\mathrm{CEC}$ (meq/100g) & 27 & 6 & 63 & 43 & 30 \\
\hline
\end{tabular}

\subsection{Removal experiments}

\subsubsection{Effect of adsorbent content}

Removal increases with solid content for a constant metal concentration of $50 \mathrm{mg} / \mathrm{L}$ (Figure 4). A plateau representing the complete removal of lead is reached at $<2 \mathrm{~g} / \mathrm{L}$ for $\mathrm{MCM}$ and $\mathrm{SCM}$, at $\sim 5 \mathrm{~g} / \mathrm{L}$ for PCM and AT_AUS and at $\sim 10 \mathrm{~g} / \mathrm{L}$ for KIM.

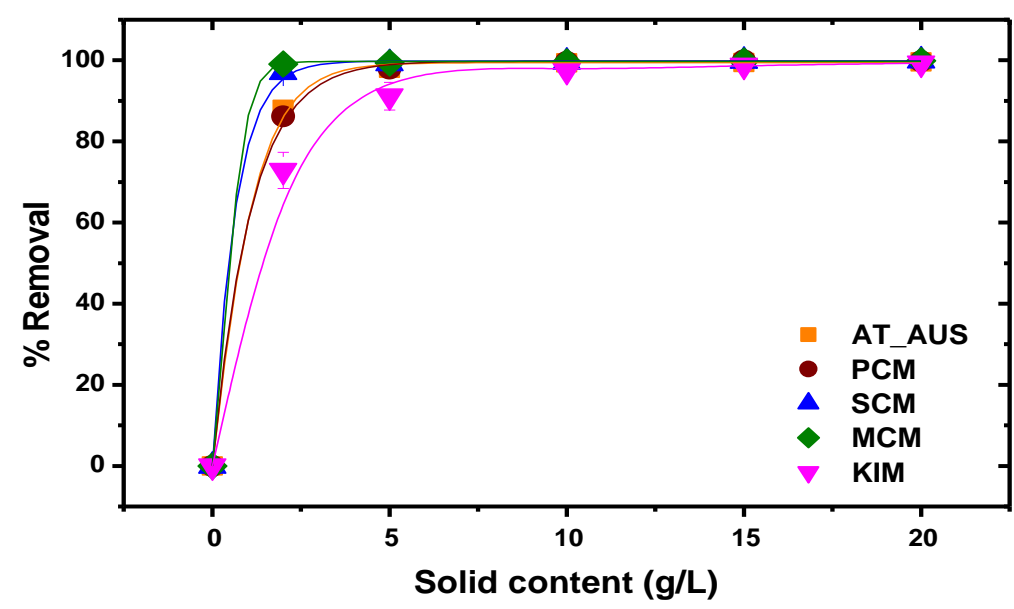

Figure 4 - Lead removal percentage (\%), as a function of solid/liquid ratio $(\mathrm{Pb}=50 \mathrm{mg} / \mathrm{L}$, contact time $24 \mathrm{~h}$, initial $\mathrm{pH}=4.5$ ). Lines are guiding the eye.

At a solid content of $2 \mathrm{~g} / \mathrm{L}$, sorbed metal loadings range from $15 \mathrm{mg} / \mathrm{g}$ (KIM) to $21 \mathrm{mg} / \mathrm{g}$ (MCM, $\mathrm{SCM})$. At $10 \mathrm{~g} / \mathrm{L}$ and higher metal concentrations $(\mathrm{Pb}=1000 \mathrm{mg} / \mathrm{L})$ the corresponding loadings 
reached $45 \mathrm{mg} / \mathrm{g}$ for both PCM and SCM samples (experimental data not shown). In general, at high mineral concentrations the available $\mathrm{Pb}$ concentration is insufficient to cover completely the exchangeable sites on the adsorbent, resulting in low heavy metal uptake. Also, higher mass of the adsorbent in the suspension may cause physical blockage of some removal sites, decreasing the removal efficiency (Malamis et al., 2013).

It is noted that the $\mathrm{pH}$ of the initial $50 \mathrm{mg} / \mathrm{L}$ lead solution is 4.5. The $\mathrm{pH}$ measured at the end of the removal experiments is higher and reaches 6.5 for KIM, 7.5 for AT_AUS and PCM, and $~ 8$ for MCM and SCM samples. The respective values in clay lead-free suspensions range between 7.5 and 8.5. This increase has been attributed to a competition between protons and lead ions onto the clay surface due to the smaller hydrated radius of the former $\left(\mathrm{H}^{+}=0.28 \mathrm{~nm}, \mathrm{~Pb}^{2+}=0.4 \mathrm{~nm}\right.$ ) (Volkov et al., 1997). The high $\mathrm{pH}$ of all suspensions indicates that precipitation of $\mathrm{Pb}$ phases is a very likely mechanism influencing the heavy metal removal from solution. This will be further discussed in paragraph 3.2.3.

\subsubsection{Removal kinetics}

Concluding that equilibrium is reached at adsorbent amount of $10 \mathrm{~g} / \mathrm{L}$, this amount was used in an attempt to study the kinetics of removal at initial solution $\mathrm{pH} 4.5$ as a function of time (Figure 5). These studies indicated that SCM, MCM and PCM reached $100 \%$ removal instantaneously ( $<5$ min). All other clay samples required longer times to disperse and, therefore, removal was heavily biased by clumping.

A pseudo- $2^{\text {nd }}$ order kinetic model seems to fit well the experimental data of KIM and AT_AUS samples $\left(\mathrm{R}^{2}=1\right)$.

\section{Equation 1 - Pseudo-2 ${ }^{\text {nd }}$ order kinetic model}

$\frac{d q}{d t}=k\left(q_{e}-q\right)^{2}$

where $\mathrm{q}$ and $\mathrm{q}_{\mathrm{e}}$ the sorbed metal concentration $(\mathrm{mg} / \mathrm{g})$ at time $\mathrm{t}$ and at equilibrium respectively, $\mathrm{k}$ the kinetic constant $\left(\min \mathrm{mg}^{-1} \mathrm{~g}^{-1}\right.$ ). The kinetic constants $\mathrm{k}$ and initial removal rates, $\mathrm{h}=\mathrm{kq}_{\mathrm{e}}{ }^{2}$, for KIM are 0.3 and 5.8, whereas for AT_AUS are 0.15 and 2.8. The above parameters are similar to those reported in the literature (Sen Gupta et al., 2011).

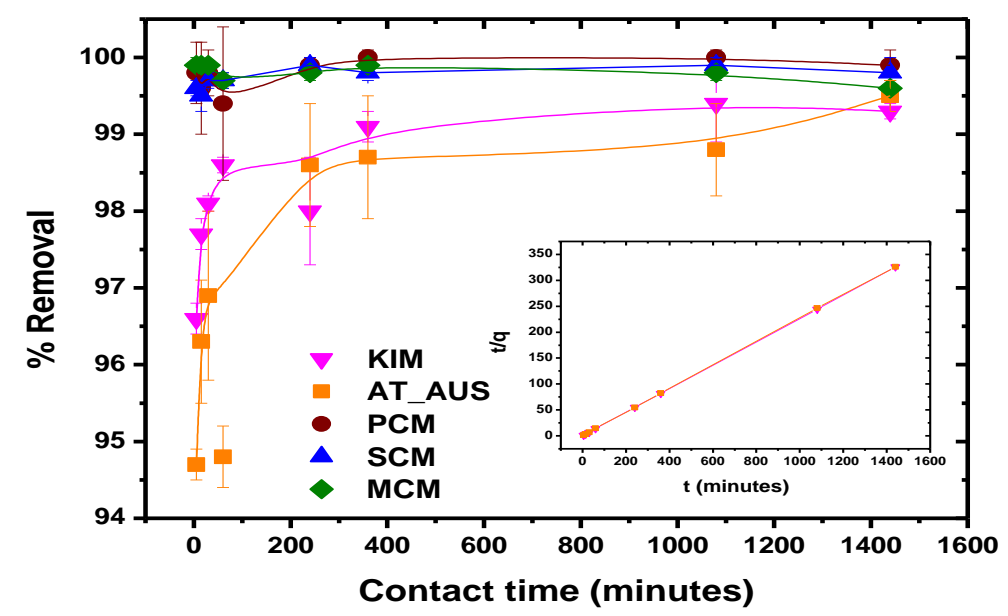

Figure 5 - Lead removal percentage $(\%)$ as a function of reaction time $(\mathrm{Pb}=50 \mathrm{mg} / \mathrm{L}$, $\mathrm{s} / \mathrm{l}=10 \mathrm{~g} / \mathrm{L}, \mathrm{pH}=4.5)$. Embedded graph corresponds to the $2^{\text {nd }}$-order kinetic removal model for KIM and AT_AUS. Lines are guiding the eye. 


\subsubsection{Effect of $\mathrm{pH}$}

The effect of the $\mathrm{pH}$ of the initial $\mathrm{Pb}^{+2}$ solution was tested in the range from 2 to 6 . At $\mathrm{pH}<3$, all clays show inferior removal percentage. The effect is more pronounced for all the studied samples with the exception of KIM sample. Specifically, at low pH $(<2.5)$ KIM exhibits the best removal performance.

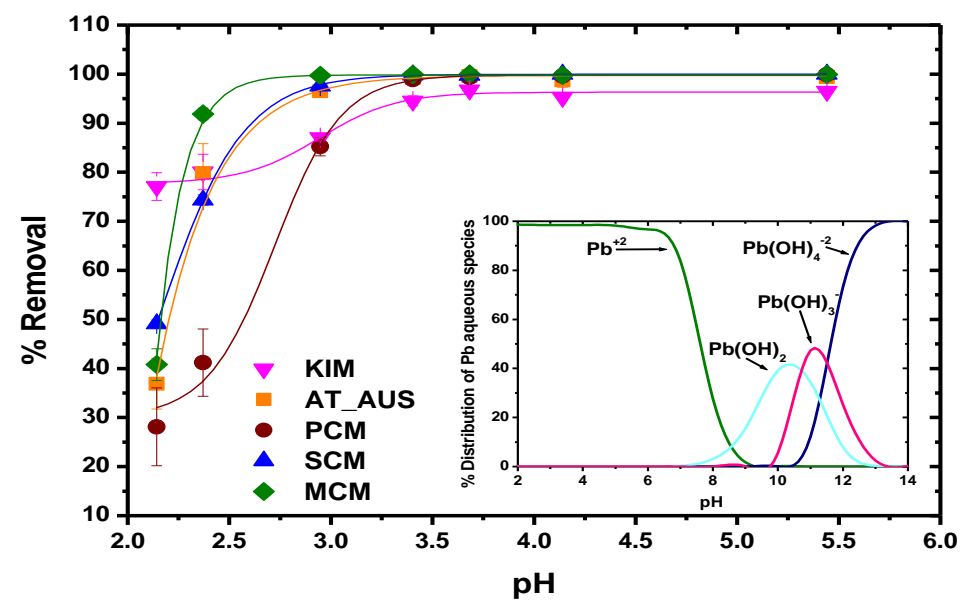

Figure 6 - Lead removal percentage (\%) as a function of solution $\mathrm{pH}(\mathrm{Pb}=50 \mathrm{mg} / \mathrm{L}$, s/l 10 $\mathrm{g} / \mathrm{L}$, contact time $4 \mathrm{~h})$. Insert graph shows $\mathrm{Pb}$ speciation with respect to $\mathrm{pH}$ as calculated by PHREEQC.

According to speciation results for Pb solubility (calculated using PHREEQC v3.2 geochemical code), $\mathrm{Pb}^{2+}$ precipitates as $\mathrm{Pb}(\mathrm{OH})_{2}$ at $\mathrm{pH}>6$ (Figure 6). The $\mathrm{pH}$ is an important removal parameter not only because it determines the speciation of $\mathrm{Pb}^{+2}$ in the solution (and therefore its precipitation), but also because it may affect the structure and morphology of the adsorbent. Extreme alkaline solutions promote the alteration of the adsorbent and induce the leaching of Si ions into the solution, whereas extreme acidic solutions leach the octahedral cations of the clay layers and create silanol groups.

\subsubsection{Effect of Ionic Strength}

The presence of additional ions in the solution affects removal in different ways for each material (Figure 7). Pb removal is inhibited at high ionic strengths, especially in KIM and to a lesser extent AT_AUS and PCM samples. On the contrary, MCM and SCM are unaffected by the K/Na presence.

The competition between the electrolyte cations, i.e. $\mathrm{Na}^{+}, \mathrm{K}^{+}$and $\mathrm{Pb}^{2+}$ for the available removal sites can decrease the amount of the heavy metal ions adsorbed on the clay (Malamis et al., 2013). If ionexchange between the exchangeable cations of the adsorbent and the $\mathrm{Pb}^{2+}$ was the primary mechanism, we should be observing a systematically large effect of ionic strength in smectites and a very small effect in palygorskites. This is observed in KIM, but not in SCM (or MCM). Furthermore, ion-exchange cannot be the main reason for the observed phenomenology, because removal performance is not correlated with the CEC. Based on the experimental observations discussed above, a mechanism involving the precipitation of $\mathrm{Pb}$-bearing phases, such as $\mathrm{Pb}$ hydroxides, on the large surface area of the alkaline adsorbent appears more plausible. In this case, removal performance would be mainly a function of the active surface of the adsorbent. The latter is determined mainly from the number of elementary particles present in the suspension (per constant mass of adsorbent in the suspension). Concerning the Grevena samples, it is noted that the active surface does not need to be a function of the mineralogical composition of the samples, and this may 
explain why no systematic trends are observed between performance on one hand and the palygorskite/ smectite ratio on the other.
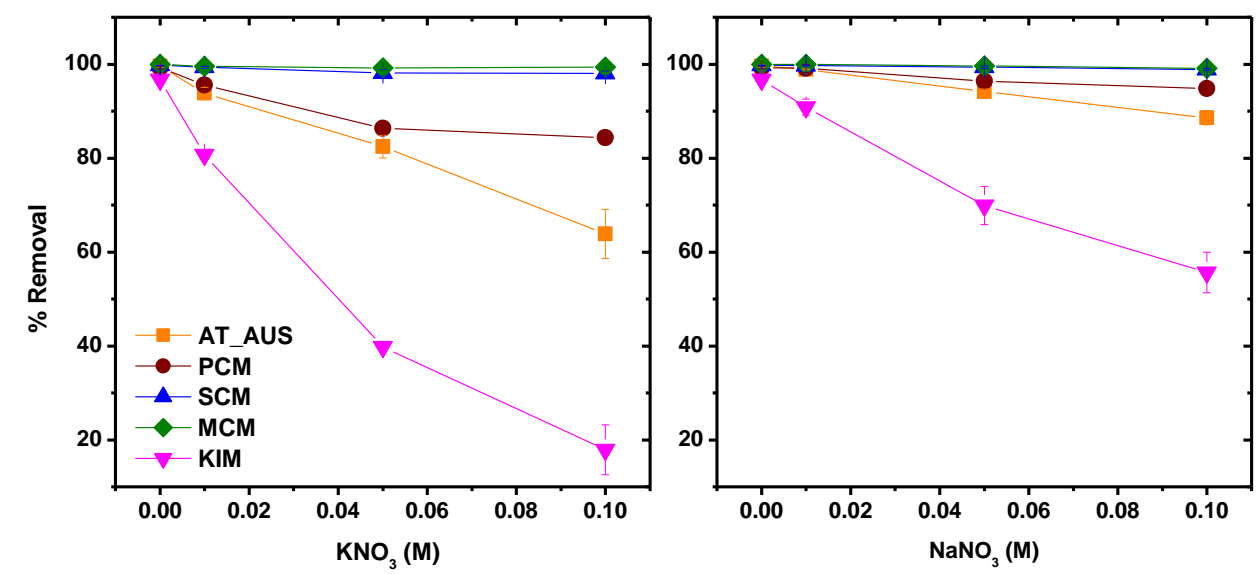

Figure 7 - $\mathrm{Pb}$ removal percentage $(\%)$ as a function of solution ionic strength $(\mathrm{Pb}=50 \mathrm{mg} / \mathrm{L}$, $\mathrm{pH}=3.6, \mathrm{~s} / \mathrm{l}=10 \mathrm{~g} / \mathrm{L}, \mathrm{t}=4 \mathrm{hr})$.

\section{Conclusions}

The performance of five clay materials has been assessed with respect to their effectiveness in removing $\mathrm{Pb}^{2+}$ from aqueous solutions. All adsorbents perform equally well at high solid to liquid ratios and long times ( $>4 \mathrm{~h}$ ) of interaction at $\mathrm{pH}>3$, by adsorbing quantitatively the $\mathrm{Pb}^{2+}$ from $50 \mathrm{mg} / \mathrm{L}$ solutions. However, based on their performance at low solids, and short reaction time it is evident that the adsorbents can be classified in the order $\mathrm{MCM}>=\mathrm{SCM}>\mathrm{PCM}=\mathrm{ATAUS}>\mathrm{KIM}$. Further, at low $\mathrm{pH}$, the removal properties are all deteriorating and KIM exhibits the best performance. Further studies are needed to elucidate the possible alteration of the adsorbent as a result of alkaline or acid leaching in the $\mathrm{pH}$ and time scales of the experiment, and its effect on removal. Also the maximum capacity of each adsorbent remains to be determined by plotting the removal isotherms with varying $\mathrm{Pb}$ concentrations in the solution. In terms of the mechanism controlling $\mathrm{Pb}$ removal from the solution our experimental data indicate that this is at least partially controlled by the active surface of the bulk clay which in turn might be related to the geological environment and type of processes that took place during the formation of the clay, e.g. hydrothermal or diagenetic alteration, precipitation etc.

\section{Acknowledgments}

The authors would like to thank Geohellas S.A. for providing the materials used in this study. Thanks are expressed to Mr. Panagiotis Oikonomou and Mr. Manolis Argyropoulos for providing us all facilities to work in bentonite Prassa Quarry at Kimolos Island, as well as Titan Cement Company S.A. for performing the XRF analysis of the samples. Last but not least, the authors acknowledge the reviewers for their comments and suggestions.

\section{References}

Bourliva, A., Michailidis, K., Sikalidis, C., Filippidis, A. and Betsiou, M., 2013. Lead removal from aqueous solutions by natureal Greek bentonites, Clay Minerals, 48, 771-787. 
Christidis, G., 1998. Physical and chemical properties of some bentonite deposits of Kimolos Island, Greece, Applied Clay Science, 13, 79-98.

Christidis, G., Katsiki, P., Pratikakis, A. and Kacandes, G., 2010. Rheological properties of palygorskite-smectite suspensions from the Ventzia Basin, W. Macedonia, Greece, Bulletin of the Geological Society of Greece, Proceedings of the 12th International Congress, Patras.

Chryssikos, G.D., Gionis, V., Kacandes, G.H., Stathopoulou, E.T., Suárez, M., García-Romero, E., and Sánchez del Rio, M., 2009. Letter: Octahedral cation distribution in palygorskite, American Mineralogist, 94(1), 200-203.

Gionis, V., Kacandes, G., Kastritis, I. and Chryssikos, G., 2007. Combined near-infrared and X-ray diffraction investigation of the octahedral sheet composition of palygorskite, Clays and Clay Minerals, 55(6), 543-553.

Kastritis, I.D., Kacandes, G.H. and Mposkos, E., 2003. The palygorskite and Mg-Fe-smectite clay deposits of the Ventzia basin, western Macedonia, Greece, Mineral exploration and sustainable development, Millpress, Rotterdam, 891-894.

Madejova, J., 2003. FTIR techniques in clay mineral studies: Review, Vibrational Spectroscopy, 31, $1-10$.

Malamis, S. and Katsou, E., 2013. A review on zinc and nickel adsorption on natural and modified zeolite, bentonite and vermiculite:Examination of process parameters, kinetics and isotherms, Journal of Hazardous Materials, 252-253 (Review), 428-461.

Potgieter, J., Potgieter-Vermaak, S. and Kalibantonga, P., 2006. Heavy metals removal from solution by palygorskite clay, Minerals Engineering, 19, 463-470.

Rhoades, J., 1990. Cation exchange capacity. In: A.L., P., Miller, R. and Keeney, D., eds., Methods of soil analysis, 2(9), 49-157, Am. Soc. Agr., Soil Sc. Soc. Am, Madison.

Sen Gupta, S. and Bhattacharyya, K., 2011. Kinetics of adsorption of metal ions on inorganic materials: A review, Advances in Colloid and Interface Science, 162, 39-58.

Stathopoulou, E.T., Suárez, M., García-Romero, E., Del Río, M.S., Kacandes, G.H., Gionis, V. and Chryssikos, G.D., 2011. Trioctahedral entities in palygorskite: Near-infrared evidence for sepiolite-palygorskite polysomatism, European Journal of Mineralogy, 23(4), 567-576.

Volkov, A., Paula, S. and Deamer, D., 1997. Two mechanisms of permeation of small neutral molecules and hydrated ions across phospholipid bilayers, Bioelectrochemistry and Bioenergetics, 42, 153-160. 